Anastasiya S. Kuzmina

student

Scientific advisor

Maria V. Pronyaeva

pedagogic sciences degree seeking applicant, associate professor, senior lecturer

Moscow Region State University

Mytishchi

DOI 10.31483/r-98830

\title{
PATENT SITUATION IN RUSSIA
}

Abstract: this article examines the patent situation in Russia, analyzes the data and, based on this analysis, draws a conclusion about the expansion of the patent in Russian Federation.

Keywords: patent, granting, Russia, inventor, indicators, patentability, innovative.

Кузьмина Анастасия Сергеевна

студентка

Научный руководитель

Проняева Мария Вадимовна

соискатель, доцент, старший преподаватель

ГОУ ВО МО «Московский государственный областной университет»

г. Мытищи, Московская область

\section{ПАТЕНТНАЯ СИТУАЦИЯ В РОССИИ}

Аннотация: в статье рассматривается патентная ситуация в России, анализируются полученные данные, и на основе этого анализа делается выводо расширении сферы действия патента в Российской Федерации.

Ключевые слова: патент, выдача грантов, Россия, изобретатель, показатели, патентоспособность, инновационный. 
A patent is the granting of a property compensated by a sovereign authority to an inventor. This subsidization supplies the artificer scoop rights to the patented process designing or invention in exchange for a full revelation of the innovation. This is a form of incorporeal compensation. A patent is issued by a chairman of the board authorization for intellectual property. In Russia this authority is Rospatent.

There are three types of patents: Utility patents (this kind of patents cover everyone who invents processes that are new and useful); Design patents (they include a new, ornamental and original design for a manufactured product.); Plant patents (this type suits everyone who produces, discovers, and invents a new kind of plant. This plant has to be capable of reproduction).

\section{PATENT ACTIVITY INDICATORS}

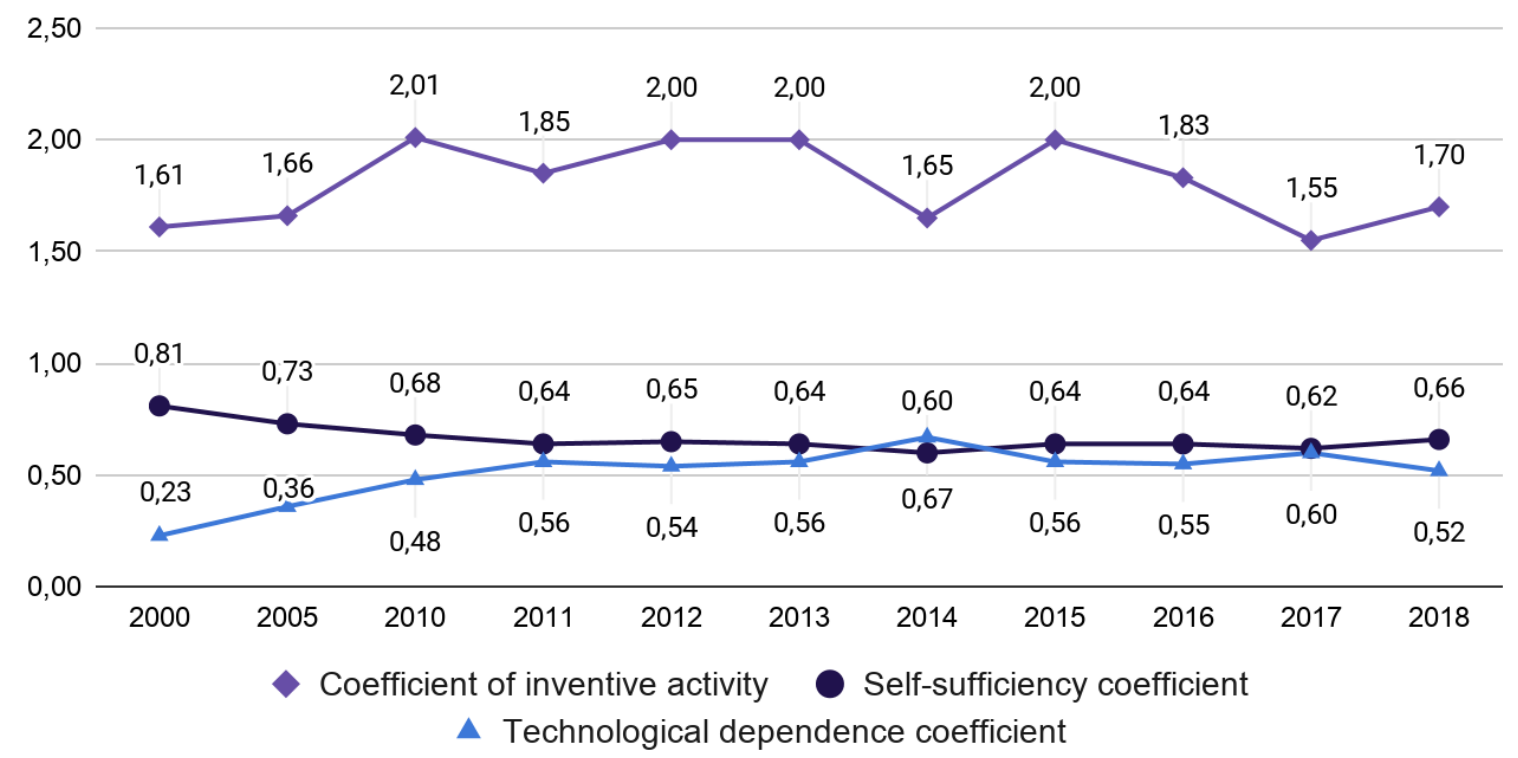

Fig. 1. Patent activity indicators

The table above shows the difference between the different coefficients. The first thing that can be clearly understood is that the coefficient of inventive activity occupies a leading position. This indicates that Russia has a high level of inventive activity. The table below shows the difference between the three coefficients. The first thing that can be clearly understood is that the coefficient of inventive activity occupies a leading position. This indicates that Russia has a high level of inventive activity. The analysis showed that the coefficient of self-sufficiency at the beginning of the 21 st century was 
much higher than the coefficient of technological dependence. However, since 2011, these indicators are almost equal.

Conditions of patentability. A patent for an invention may be granted if the invention encounters three main conditions of patentability: Invention must be new (unknown from the existing state of the art); It must have an inventive level (the proposed solution for a specialist does not explicitly follow from the state of the art); It must be used in industry, agriculture and other industries. The compliance of the invention with the conditions of patentability is determined by the state examination. If in the course of the examination it turns out that the invention meets the three specified conditions, in this case, the applicant may be granted a patent.

Patenting in Russia. To patent an invention, you need to go through the patenting procedure in Rospatent. It consists of 7 steps. The first one and the most important is a patent search. Before conducting a patent search, you need to accurately determine the subject of the search. If you have several search directions, you need to choose one of them, because searching in all directions will take a lot of time.

Types of patent search. There are several types of patent search: thematic; name search and search for analogous patents; numbering; search to identify patent rights. The description of each copyright certificate or patent contains the mandatory standard elements. For example, the number of the author's certificate or patent; name of the invention; ICI index (International Classification of Inventions); priority date; etc.

International Classification of Inventions (ICI) was created in 1954 in order to correctly dispense all the inventions and to find the necessary ones. In general, the ICI consists of eight sections: Meeting the vital needs of a person (A); various technological processes (B); chemistry and metallurgy (C); textiles, paper (D); construction, mining (E); mechanics, lighting, heating, engines and pumps, weapons, ammunition, blasting $(\mathrm{F})$; physics $(\mathrm{G})$; electricity $(\mathrm{F})$. 


\section{Distribution of granted patents of the Russian Federation: 2018}

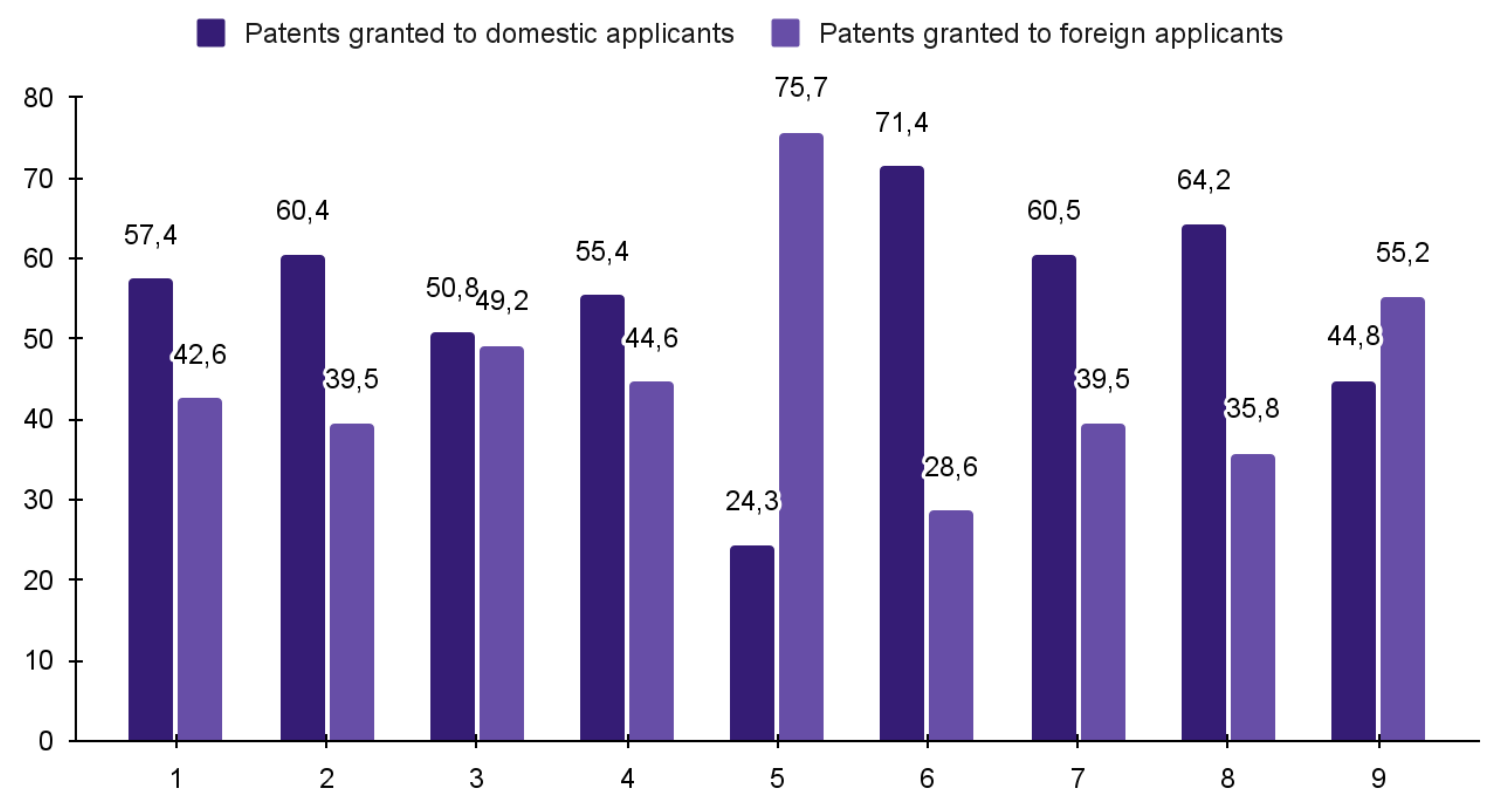

Fig. 2

The two columns below the number 1 show the overall picture. It immediately becomes clear that patents issued to domestic applicants occupy a leading position (57.4\%). The biggest difference can be seen under the numbers 5 and 6 , which are responsible for textiles, paper and construction, mining, respectively. This is due to the development and demand for certain areas in the country.

The analysis of the above data leads us to the conclusion that the patent situation in Russia is gaining momentum and there is no reason to think about its decline. However, it is necessary to pay attention to those points that are slowly developing and take appropriate measures to improve the situation.

\section{Список литературы}

1. Indicators of science: 2020: statistical collection / L.M. Gokhberg, K.A. Ditkovsky, E.I. Evnevich.; Nats. research. Higher School of Economics Univ., Moscow. HSE, $2020-337$ p.

2. Indicators of science: 2021: statistical collection / L.M. Gokhberg, K.A. Ditkovsky, E.I. Evnevich.; Nats. research. Higher School of Economics Univ., Moscow. HSE, $2021-352$ p. 
3. Intellectual Property Office. Manual of patent practice. URL: https://www.gov.uk/guidance/manual-of-patent-practice-mopp/section-1-patentability (date of request: 21.04.2021).

4. FindLaw's team. Types of patents. URL: https://www.findlaw.com/smallbusiness/intellectual-property/types-of-patents.html (date of request: 21.04.2021). 